\title{
WPŁYW PANDEMII COVID-19 NA ZASIĘG ODDZIAŁYWANIA PORTU LOTNICZEGO POZNAŃ-ŁAWICA
}

\section{THE INFLUENCE OF THE COVID-19 PANDEMIC ON THE CATCHMENT AREA OF POZNAŃ-ŁAWICA AIRPORT}

\author{
Radosław Bul
}

Uniwersytet im. Adama Mickiewicza w Poznaniu, Wydział Geografii Społeczno-Ekonomicznej i Gospodarki Przestrzennej, Poznań, Polska, (D) https://orcid.org/0000-0002-6617-1473, e-mail: bul@amu.edu.pl

\begin{abstract}
Streszczenie
Celem niniejszego opracowania było określenie zasięgu oddziaływania Portu Lotniczego Poznań-Ławica w kontekście działalności pozostałych lotnisk w kraju. Analiza została przeprowadzona w czasie pandemii COVID-19, która znacząco wpłynęła na funkcjonowanie transportu lotniczego w Polsce i na świecie. Drugim istotnym celem opracowania o charakterze metodologicznym było dokonanie oceny możliwości wykorzystania modelu Huffa jako sposobu określania siły oddziaływania poszczególnych portów lotniczych w Polsce, w tym Portu Lotniczego Poznań-Ławica. W ramach pracy analizie poddano zmiany zasięgu oddziaływania lotnisk w latach 2019-2020, które są skutkiem pandemii przejawiającej się przede wszystkim zmianą oferty przewozowej poszczególnych lotnisk. Wyniki analiz wskazują, że pozostałe lotniska w kraju w znaczącym stopniu oddziałują na region i mocno wpływają na rynek usług lotniczych na obszarze województwa wielkopolskiego, a lotnisko Poznań-Ławica jest obiektem pierwszego wyboru zwłaszcza dla mieszkańców centralnej części regionu. Analizy zawarte w pracy wskazują także na niewielkie zmniejszenie się zasięgu oddziaływania lotniska na skutek pandemii.
\end{abstract}

Słowa kluczowe: model Huffa, pandemia COVID-19, Port Lotniczy Poznań-Ławica, transport lotniczy.

Bul R. (2021). Wpływ pandemii Covid-19 na zasięg oddziaływania Portu Lotniczego Poznań-Ławica. Czasopismo Geograficzne 92(1): 95-120. https://doi.org/10.12657/czageo-92-05

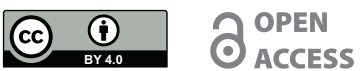




\begin{abstract}
The aim of this study was to determine the catchment area of Poznań-Ławica Airport against the background of other airports in the country. The analysis was carried out during the COVID-19 pandemic, which had significantly influenced the functioning of air transport in Poland and in the world. The second important aim of the research was to assess the possibility of using Huff's model as a method of determining the catchment area of airports in Poland, particularly Poznań-Ławica Airport. As a part of the work, the changes in the of airports between 2019 and 2020 that followed the pandemic were analysed. The results of the analyses show that other airports in the country have a significant impact on the Wielkopolska region and strongly affect the market of air services in the voivodeship. The findings also indicate a slight decrease in the Poznan airport catchment area as a result of the pandemic.
\end{abstract}

Keywords: air transport, COVID-19 pandemic, Huff's model, Poznań-Ławica Airport.

\title{
WPROWADZENIE
}

Pandemia COVID-19 niewątpliwie miała istotny wpływ na gospodarkę światową. Według szacunków podawanych przez GUS w roku 2020 odnotowano pierwszą od ponad 30 lat recesję gospodarczą w Polsce na poziomie 2,8\%. Znaczące ograniczenia w przemieszczaniu się osób, przede wszystkim w skali międzynarodowej, wymusiły wdrożenie nowych rozwiązań, głównie z sektora łączności, celem realizacji dotychczasowej działalności i wykonywania obowiązków zawodowych. Ograniczenia mobilności doprowadziły do redukcji zapotrzebowania na usługi transportowe i przesunięcia modalnego $\mathrm{w}$ transporcie.

Gałęzią transportu, która niewątpliwie najmocniej odczuła skutki pandemii, jest transport lotniczy. Jeszcze 2 lata temu prognozy rozwoju rynku lotniczego w Polsce wskazywały na dynamiczny wzrost liczby pasażerów na krajowych lotniskach, zwłaszcza w portach regionalnych (Pijet-Migoń, 2012). Tymczasem pandemia, która wybuchła w marcu 2020 r., skutkowała zmniejszeniem ruchu pasażerskiego w okresie od marca 2020 do maja 2020 r. o 90\%, co miało dramatyczne konsekwencje dla dochodów wszystkich uczestników sektora i ich pracowników w łańcuchu wartości w lotnictwie (Paprocki i in., 2020). Z uwagi na ograniczenia mobilności, szczególnie przemieszczeń o zasięgu międzynarodowym (Zając, 2020) wiele lotów zostało od początku pandemii odwołanych, co więcej - trudno było planować kolejne miesiące funkcjonowania tej formy transportu. Od momentu wybuchu pandemii wyraźnie dostrzec można okresy intensyfikacji działalności linii lotniczych (czas urlopowo-wakacyjny) i okresy (zwłaszcza w trakcie kolejnych tzw. „fal zakażeń”), kiedy transport lotniczy w portach znaczenia regionalnego niemalże zamiera. W związku z zaistniałą sytuacją wiele linii lotniczych stara się odnaleźć niszę przewozową i uruchomić flotę, która przez znaczną część roku nie jest wykorzystywana. Stąd też wzrost liczby połączeń w okresach waka- 
cyjnych obsługiwanych przez linie regularne (segment legacy) czy niskokosztowe (segment low-cost).

Do nowej sytuacji muszą też przystosować się porty lotnicze, które po wielu latach intensywnego rozwoju ruchu lotniczego (Tłoczyński, 2016) straciły znaczną część klientów. Szczególne wyzwanie dotyczy portów regionalnych, które nie tworzą wielkich hubów przesiadkowych, a są raczej punktami dostępowymi do sieci transportu lotniczego. Typowym lotniskiem regionalnym jest Port Lotniczy Poznań-Ławica, którego podstawową funkcją jest zapewnienie dobrej dostępności transportowej mieszkańcom województwa wielkopolskiego. Województwo z uwagi na swój duży obszar znajduje się także w strefie oddziaływania innych portów lotniczych. Oddziaływanie to jest pochodną wielu aspektów, z których najistotniejsze wydają się: oferta danego lotniska i jego dostępność przestrzenna. Spora grupa pasażerów wskazuje też na wagę dostępności cenowej oferty przy okazji wyboru portu lotniczego, z którego korzystają (Bul, 2018). Oczywiście $\mathrm{w}$ czasach pandemii kryteria te odgrywają drugorzędną rolę, decyduje przede wszystkim oferta przewozowa danego portu. Zasadna zatem wydaje się potrzeba zbadania zmian zasięgu oddziaływania Portu Lotniczego Poznań-Ławica w okresie pandemii w kontekście funkcjonowania sąsiednich portów lotniczych.

Celem opracowania było określenie zasięgu oddziaływania Portu Lotniczego Poznań-Ławica w kontekście działalności pozostałych lotnisk w kraju. Analiza została przeprowadzona w czasie pandemii COVID-19, która znacząco wpłynęła na funkcjonowanie transportu lotniczego w Polsce i na świecie. Drugim istotnym celem o charakterze metodologicznym było dokonanie oceny możliwości wykorzystania modelu Huffa jako metody służącej do określenia siły oddziaływania poszczególnych portów lotniczych w Polsce, w tym Portu Lotniczego PoznańŁawica. W ramach pracy analizie poddano zmiany zasięgu oddziaływania lotnisk w latach 2019-2020, które są skutkiem pandemii przejawiającej się przede wszystkim zmianą oferty przewozowej poszczególnych portów. Wpływ na zasięg oddziaływania lotnisk ma także dostępność transportowa, która $\mathrm{w}$ analizowanym okresie uległa zmianie na skutek rozbudowy sieci drogowej w kraju.

Tematyka wpływu pandemii COVID-19 na transport lotniczy jest jednym z najczęściej poruszanych $\mathrm{w}$ ostatnim czasie zagadnień $\mathrm{w}$ ramach prac z zakresu geografii transportu. Dominują opracowania o charakterze empirycznym, prezentujące wpływ pandemii na skalę i kierunki przemieszczeń wykonywanych $\mathrm{w}$ zróżnicowanych skalach przestrzennych, od analiz na poziomie krajowym i międzynarodowym po studia przypadków, które ukazują najczęściej działalność poszczególnych portów lotniczych. Interesującą w ramach analizowanej tematyki pracę przedstawił m.in. Nizetić (2020), który zbadał zmiany, jakie zaszły na skutek pandemii w ujęciu globalnym, że szczególnym uwzględnieniem portów zlokalizowanych w Zagrzebiu i Splicie. Podobna tematyka cechowała pracę Taşdemira (2020), który analizował skutki pandemii COVID-19 dla sektora lotniczego na 
przykładzie największych lotnisk w Turcji. Interesujące są też prace, które analizują wpływ pandemii na przesunięcie modalne w ramach różnych gałęzi transportu i zmiany zachowań transportowych ludności. Powyższe zagadnienie omawiane było m.in. w ramach pracy autorstwa Ki-Han i Solsaem (2021), w której przedstawiono zmiany, jakie zaszły w kontekście wykorzystania transportu lotniczego przez mieszkańców Korei Południowej. Istotną grupę opracowań stanowią publikacje o charakterze prognostycznym, w ramach których autorzy przedstawiają analizy dotyczące funkcjonowania transportu lotniczego w przyszłości. Z tego zakresu warto wskazać chociażby na pracę Serrano i Kazdy (2020), której przedmiotem jest analiza potencjału przewozowego w najbliższych latach oraz prognozowane zmiany wykorzystania infrastruktury lotniskowej (w tym terminali lotniczych), które zdaniem autorów będą zachodzić na skutek pandemii.

Tematyka wpływu pandemii na transport lotniczy jest też przedmiotem zainteresowania nauk ekonomicznych. Liczne prace dotyczą oddziaływania pandemii na finansowanie i sposoby zarządzania infrastrukturą transportową. Wiele publikacji podejmuje zagadnienia pomocy publicznej we wspieraniu portów i przewoźników w sytuacji znacznego ograniczenia pracy przewozowej. W tym kontekście szczególnie interesująca jest praca Abate i in. (2020), której przedmiotem jest analiza wsparcia sektora transportu lotniczego ze strony rządowej. Autorzy pracy wskazują m.in. na czynniki, które kształtują gotowość rządów do wspierania linii lotniczych, a następnie analizują przykłady wdrożenia działań w wymiarach istotnych dla polityki transportu lotniczego, m.in. konkurencji i liberalizacji rynku oraz jej wpływu na środowisko.

\section{METODY BADAŃ}

W ramach artykułu przeanalizowano dostępność przestrzenną i zasięg oddziaływania lotniska Poznań-Ławica na tle 14 pozostałych portów lotniczych w kraju. Co warte zaznaczenia na wstępie, $\mathrm{z}$ uwagi na ograniczenia zastosowanej metody badawczej w analizach nie uwzględniono oddziaływania lotniska w Berlinie (Portu Lotniczego Berlin-Brandenburg im. Willyego Brandta), które od października 2020 r. zastąpiło lotniska Tegel i Schönefeld. Niestety wykorzystywany w pracy do oceny zasięgu poszczególnych portów model Huffa nie uwzględnia aspektu istnienia granicy państwa, która dla wielu osób stanowi barierę w dostępie do danego lotniska. Trudno określić, jak wielki odsetek podróżujących rezygnuje z korzystania z usług lotniska $\mathrm{w}$ Berlinie z uwagi na konieczność przemieszczenia się do innego kraju (i wynikających $\mathrm{z}$ tego kwestii, takich jak chociażby potrzeba posługiwania się obcym językiem czy w czasach intensyfikacji zachorowań na COVID-19 konieczności odbycia kwarantanny). W celu określenia zasięgu oddziaływania lotnisk zlokalizowanych poza granicami kraju konieczne byłoby przeprowadzenie dodatkowych badań, które pomogłyby we wskazaniu udziału 


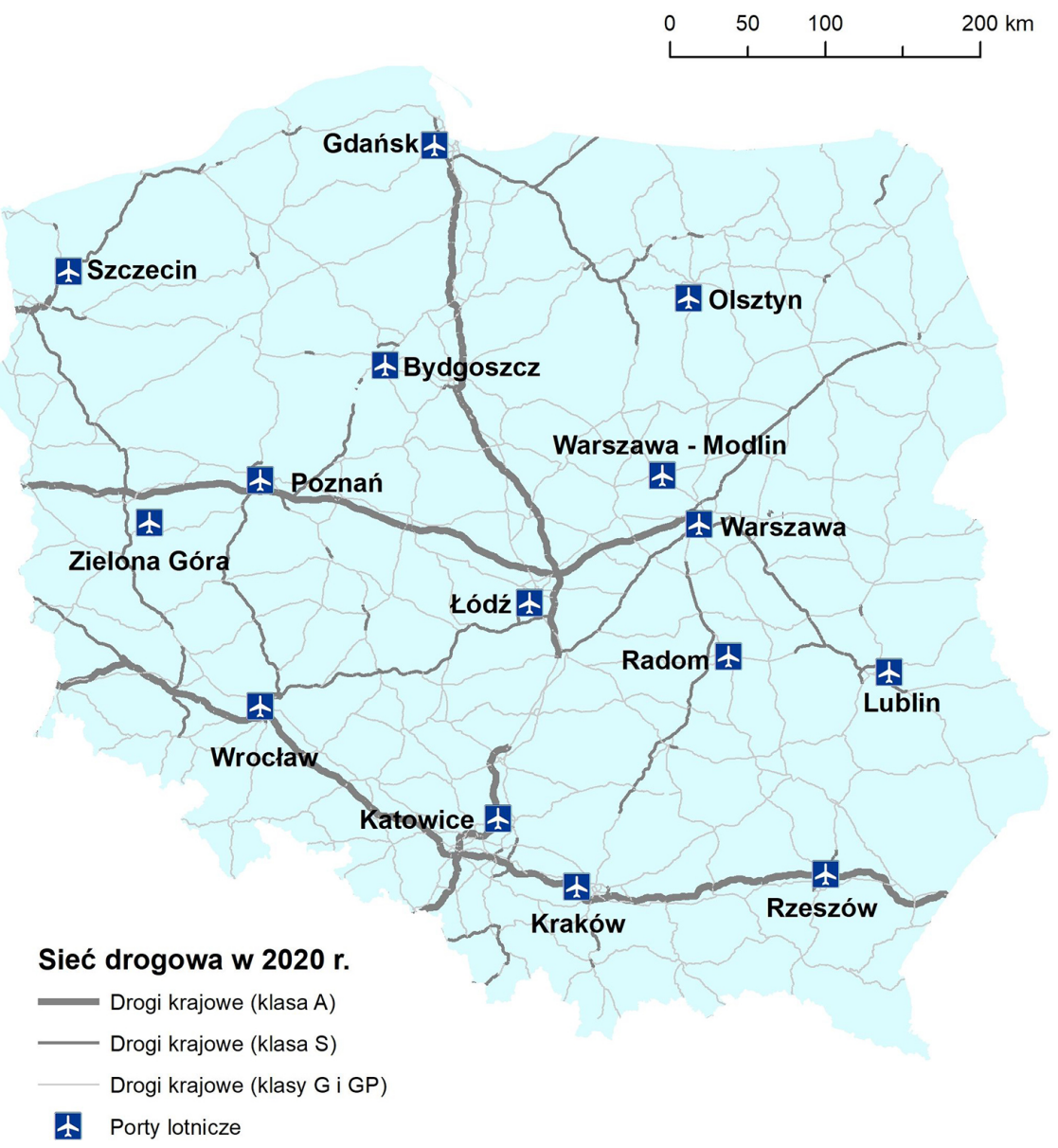

Ryc. 1. Lokalizacja portów lotniczych na tle sieci drogowej w Polsce Źródło: opracowanie własne na podstawie bazy danych OSM (2021).

osób, dla których dojazd do Berlina w czasie pandemii nie stanowiłby problemu. Autor opracowania ma pełną świadomość faktu, że prowadzone analizy w kontekście oddziaływania portów lotniczych zlokalizowanych w zachodniej części kraju mogą w pewien sposób odbiegać od rzeczywistości z uwagi na oddziaływanie lotniska w Berlinie. Lokalizację analizowanych w opracowaniu lotnisk na tle sieci drogowej kraju prezentuje rycina 1.

Wszystkie analizy przedstawione $\mathrm{w}$ pracy wykonano w oparciu o dane prezentujące liczbę pasażerów korzystających z usług danego lotniska w roku 2019 i 2020, które pozyskano z Urzędu Lotnictwa Cywilnego oraz stron internetowych portów lotniczych. Do oceny zasięgu oddziaływania Portu Lotniczego PoznańŁawica i pozostałych ośrodków wykorzystano jeden z najpopularniejszych modeli ciążenia do ośrodków miejskich - model probabilistyczny Huffa (zwany też 
modelem grawitacji względnej Huffa), opracowany przez D.L. Huffa w 1962 r. (por. Brol, 2014). Należy on do grupy stochastycznych modeli lokalizacji usług skierowanych do ludności i wyraża prawdopodobieństwo wyboru danego miejsca spośród konkurujących ze sobą ośrodków i skorzystania z usługi w określonej lokalizacji. Model najczęściej stosowany jest do analiz rynkowych w kontekście dostępności towarów i usług handlowych, np. do poszukiwania lokalizacji pod budowę obiektów handlu detalicznego (por. Czyż, 2002; Chojnicki, 2011). Od pewnego czasu wykorzystuje się również model Huffa w analizach dostępności i potencjału obiektów infrastrukturalnych związanych z dziedziną transportu. Jednym z takich typów obiektów są porty lotnicze.

Według L.D. Huffa czas podróży i wielkość ośrodka są czynnikami wpływającymi na zachowanie konsumenta i mogą służyć do przewidywania wyboru miejsca skorzystania z danej usługi (Huff, 1964). Zgodnie z powyższym założeniem prawdopodobieństwo wyboru rzeczonego miejsca wyraża się wzorem (Huff, 1963):

$$
P_{i j}=\frac{\frac{S_{j}}{T_{i j}^{a}}}{\sum_{j=1}^{n} \frac{S_{j}}{T_{i j}^{a}}}
$$

gdzie:

$P_{i j}$ - prawdopodobieństwo, że pojedynczy mieszkaniec regionu uda się, by skorzystać z usługi, do miejsca j;

$S_{j}$ - potencjał danego miejsca (wielkość placówki, powierzchnia sprzedaży wyrobów danej branży, oferta przewozowa) w miejscu j;

$T_{i j}$ - czas niezbędny na przemieszczenie się konsumenta $\mathrm{z}$ regionu i do miejsca zakupów $j$;

$a$ - parametr szacowany empirycznie, odzwierciedlający wpływ czasu podróży na przemieszczenia związane z zakupami (różny dla różnych grup towarów i usług).

Obliczenie wartości prawdopodobieństwa skorzystania z usług na danym obszarze pozwala na stworzenie mapy izolinii prezentujących zasięg poszczególnych ośrodków. Przecięcie się linii zakreślonych wokół ośrodków na poziomie prawdopodobieństwa wynoszącym 50\% wyznacza punkt graniczny i wskazuje zasięg, w którym dana placówka stanowi obiekt pierwszego wyboru dla potencjalnego klienta.

Powyższy model został wykorzystany do wyznaczenia zasięgu oddziaływania Portu Lotniczego Poznań-Ławica na tle pozostałych portów lotniczych w kraju. Do obliczenia prawdopodobieństwa skorzystania z usług danego portu lotniczego 
niezbędne były informacje statystyczne określające potencjał danego portu oraz dane obrazujące dostępność poszczególnych analizowanych lotnisk.

Jako wartość wyrażającą potencjał danego lotniska przyjmuje się najczęściej liczbę pasażerów, korzystających z usług portu lotniczego w ciągu roku kalendarzowego. Wartość ta pozwala uwzględnić wiele zmiennych, gdyż liczba pasażerów zależy od liczby połączeń i częstotliwości, jest również pochodną zapełnienia samolotów, wskazuje zatem na zainteresowanie danym połączeniem. Zdaniem autora o potencjale danego portu lotniczego świadczy też sama liczba destynacji, jednakże w czasie pandemii COVID-19, kiedy oferta przewozowa zmienia się dynamicznie, trudno jednoznacznie wskazać realnie liczbę połączeń oferowanych z danego portu. Oczywiście takie elementy, jak cena oraz częstotliwość lotu odgrywają rolę przy wyborze lotniska, jednakże ich znaczenie jest coraz mniejsze, wiele osób preferuje lot przede wszystkim z najbliżej zlokalizowanego portu lotniczego, o ile może z niego skorzystać z połączenia. Wydaje się zatem, że wykorzystanie danych dotyczących liczby pasażerów z określonego portu jest w obecnej sytuacji jedyną miarą, której można użyć do zobrazowania potencjału danego portu.

Drugą zmienną wpływającą na ocenę prawdopodobieństwa skorzystania z lotniska była dostępność transportowa poszczególnych portów lotniczych. Przyjęto, że w przypadku powyższych analiz dostępność transportowa zostanie wyrażona poprzez czas dojazdu samochodem (dostępność drogową). W tym celu opracowano model dostępności czasowej, w którym zastosowano metody geostatystyczne. W oparciu o metodę opracowaną przez Juliao (1998) i wykorzystywaną m.in. przez Gadzińskiego (2013) stworzono mapę rastrową zawierającą informację o czasie dojazdu do poszczególnych lotnisk z obszaru całego kraju.

Pierwszym krokiem do opracowania mapy dostępności było przekształcenie za pomocą oprogramowania ARC GIS warstwy wektorowej sieci drogowej pozyskanej z bazy danych OSM uzupełnionej o informację na temat prędkości przemieszczania się poszczególnymi odcinkami dróg na warstwę rastrową o stałej wielkości boku piksela równej $500 \mathrm{~m}$. Odcinkom dróg przypisano wartości prędkości w zależności od kategorii i klasy drogi oraz występujących ograniczeń (autostrady - $140 \mathrm{~km} /$ godz., drogi ekspresowe - $120 \mathrm{~km} /$ godz., drogi krajowe i wojewódzkie - $90 \mathrm{~km} /$ godz., drogi powiatowe - $70 \mathrm{~km} /$ godz., inne drogi utwardzone: $50 \mathrm{~km} /$ godz., drogi nieutwardzone $-20 \mathrm{~km} /$ godz.), natomiast tym poza drogami - wartość $4 \mathrm{~km} /$ godz. (możliwość pieszego dojścia do zaparkowanego przy drodze pojazdu) (Gadziński, 2013). W przypadku występowania kilku odcinków dróg różnej kategorii bądź klasy oprogramowanie przyznawało priorytet drodze o najwyższych parametrach (najwyższej potencjalnej prędkości).

Po wykonaniu konwersji na plik rastrowy kolejnym etapem było przeliczenie wartości wyrażonych w kilometrach na godzinę na wartości czasowe. Zastosowano do tego proste przeliczenie według wzoru: 


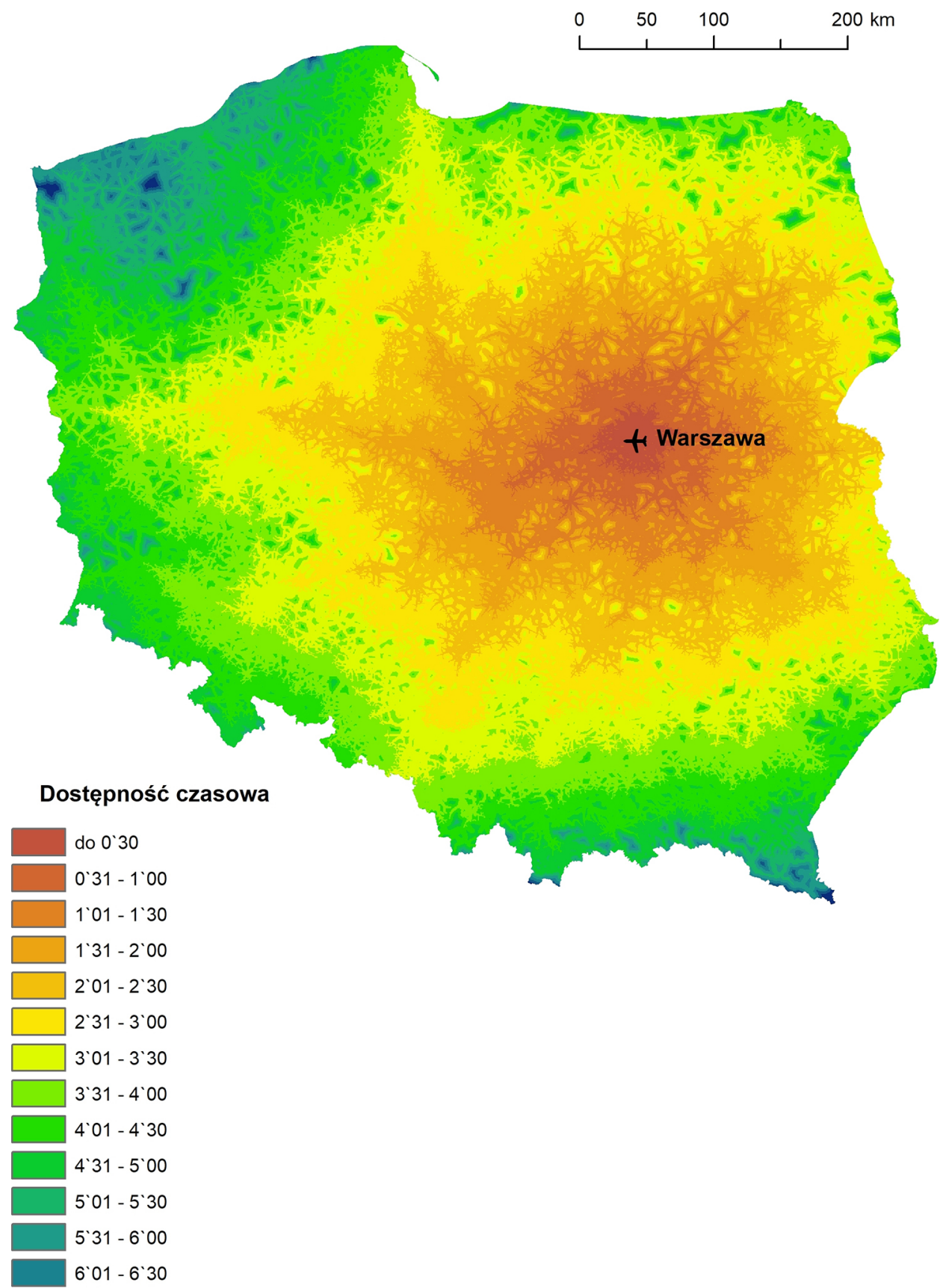

Ryc. 2. Dostępność czasowa Lotniska Chopina w Warszawie w roku 2020

Źródło: opracowanie własne. 


$$
T_{p}[\min ]=\frac{R[\mathrm{~m}] \times 60}{V\left[\frac{\mathrm{km}}{\mathrm{h}}\right] \times 1000}
$$

gdzie:

$T_{p}$ - czas potrzebny na przejazd przez piksel,

$R$ - długość piksela (500 m),

$V$ - prędkość przejazdu/przejścia przez piksel.

W efekcie otrzymano raster z przypisanymi poszczególnym pikselom wartościami czasowymi wyrażonymi w minutach. W kolejnym etapie przy użyciu narzędzia CostDistance w programie ARC GIS zbudowano plik rastrowy prezentujący odległość czasową do portów lotniczych. Wykorzystane narzędzie sumowało kolejne wartości pikseli w miarę oddalania się od analizowanego obiektu (wybierając minimalne wartości). W efekcie powstał obraz, w którym piksele na obszarach najbardziej dostępnych mają najniższe wartości (wyrażone w minutach). Natomiast im mniejsza dostępność, tym pikselom przypisana jest wyższa wartość (Gadziński, 2013). Ostatnim etapem było wykonanie map i podział na klasy według czasu dojazdu. Niniejszą analizę sporządzono dla wszystkich portów lotniczych w kraju. Przykładową mapę dostępności Lotniska Chopina w Warszawie z obszaru Polski zaprezentowano na rycinie 2.

W oparciu o dane obrazujące liczbę pasażerów w latach 2019 i 2020 oraz dostępność transportową obliczono prawdopodobieństwo skorzystania z usług w ramach danego portu lotniczego w oparciu o wspomniany powyżej model Huffa. Obliczeń dokonano przy użyciu narzędzia Map Algebra, dostępnego w ramach oprogramowania ARC GIS 10.5. Wyniki analiz przedstawiono na kolejnych rycinach.

W ramach opracowania wykonano ryciny prezentujące zasięg oddziaływania Portu Lotniczego Poznań-Ławica w latach 2019 i 2020, a także mapę ukazującą zmiany tego zasięgu na skutek pandemii i zmiany oferty przewozowej. Wykonano też mapę zasięgu oddziaływania wszystkich lotnisk w kraju w roku 2020.

\section{WYNIKI BADAŃ I DYSKUSJA}

\section{Oferta i dostępność Portu Lotniczego Poznań-tawica}

Transport lotniczy jest niewątpliwie jednym z sektorów gospodarki, który najbardziej ucierpiał na skutek pandemii COVID-19, stąd analiza potencjału poszczególnych portów i ich oferty przewozowej jest niezwykle ważnym zadaniem. W warunkach przedpandemicznych czynnikami mającymi istotny wpływ na wybór oferty danego portu lotniczego były m.in. dostępność portu, dostępność określo- 
nej destynacji (patrz Augustyniak, Olipra, 2014), dostępność cenowa połączenia, wygoda pasażera, częstotliwość połączenia czy możliwość przesiadki na inny lot (Bul, 2018). Niestety z uwagi na często zmieniającą się sytuację epidemiczną od początku pandemii bardzo trudno określić aktualny potencjał poszczególnych portów. Jeden ze wskaźników do tej pory stosowanych w postaci analizy liczby destynacji jest w zasadzie bezużyteczny, pandemia COVID-19 znacząco wpłynęła na częstotliwości lotów i siatkę połączeń. Port Lotniczy Poznań-Ławica w roku 2019 oferował w sezonie letnim połączenia do 71 destynacji. Po wybuchu pandemii w roku 2020 od marca do maja loty praktycznie zawieszono, po czym w sezonie letnim oferta powróciła do poziomu z roku 2019. Z kolei po zakończeniu sezonu letniego 2020 liczba połączeń była wyraźnie mniejsza aniżeli w poprzednich latach, co przełożyło się na liczbę pasażerów odprawionych w ciągu roku.

Co istotne dla oceny oferty przewozowej, sezon letni oraz jesień $2021 \mathrm{r}$. zapowiadały się w przypadku Portu Lotniczego Poznań-Ławica szczególnie interesująco, o czym świadczy rekordowa liczba połączeń oferowanych przez linie regularne i niskokosztowe (45) oraz bogata oferta połączeń czarterowych, która obejmuje także 4 kierunki pozaeuropejskie (Tajlandię, Meksyk, Dominikanę i Kubę). Zgodnie z zapowiedziami przewoźników jesienią 2021 r. oferta lotniska miała obejmować 81 destynacji, co oznacza, że liczba kierunków będzie większa niż w rekordowym 2019 r., przed wybuchem pandemii. Warto dodać, że zdecydowana większość oferowanych kierunków to destynacje o charakterze turystyczno-wypoczynkowym, co w pewnym stopniu wskazuje na wzrost wykorzystania transportu lotniczego w celach stricte turystycznych kosztem lotów realizowanych $w$ innych celach. Niestety $z$ uwagi na kolejne mutacje koronawirusa liczba oferowanych destynacji z lotniska może ulec zmianie, zatem ocena oferty portów lotniczych w kraju w zasadzie nie jest do końca możliwa, a jedynym wskaźnikiem, który mógłby w jakimś stopniu oddać potencjał danego portu, jest liczba pasażerów w ujęciu miesięcznym czy rocznym. Szczególnie ten ostatni wskaźnik wydaje się zasadny, przede wszystkim z uwagi na fakt zróżnicowanych typów ruchu realizowanych z poszczególnych portów w kraju, co przekłada się na liczbę pasażerów obsługiwanych $\mathrm{w}$ danych miesiącach w ciągu roku.

Dane przedstawione przez Urząd Lotnictwa Cywilnego dotyczące liczby pasażerów, którzy skorzystali z usług portów w kraju, wskazują na znaczący spadek liczby osób korzystających z transportu lotniczego w roku 2020 w stosunku do roku 2019. Liczba osób, które skorzystały z transportu lotniczego ze wszystkich lotnisk w Polsce, spadła z $49 \mathrm{mln}$ w roku 2019 do 14,5 mln w roku 2020. Powyższy wynik oznacza, że w roku 2020 obsłużono w polskich portach jedynie $29,68 \%$ pasażerów z roku poprzedniego. Pandemia nie wpłynęła na pozycję poszczególnych portów w hierarchii lotnisk w kraju. Nadal najważniejszym polskim portem jest Lotnisko Chopina w Warszawie, następne miejsca zajmują porty w Krakowie, Gdańsku, Katowicach, Wrocławiu, Modlinie i Poznaniu. Co warte odnotowania, 
w roku 2020 tylko 5 polskich lotnisk obsłużyło więcej niż 1 mln pasażerów (piąty w kolejności Wrocław przekroczył tę granicę nieznacznie). Dane dotyczące liczby pasażerów obsłużonych w portach lotniczych w Polsce w latach 2019 i 2020 przedstawiono na rycinie 3 i w tabeli 1 .

Analizując dane dla Portu Lotniczego Poznań-Ławica w roku 2020 dostrzec można wyraźny spadek liczby osób korzystających $\mathrm{z}$ lotniska w stosunku do roku poprzedniego. W roku 2019 z usług portu skorzystało ponad 2,37 mln pasażerów,

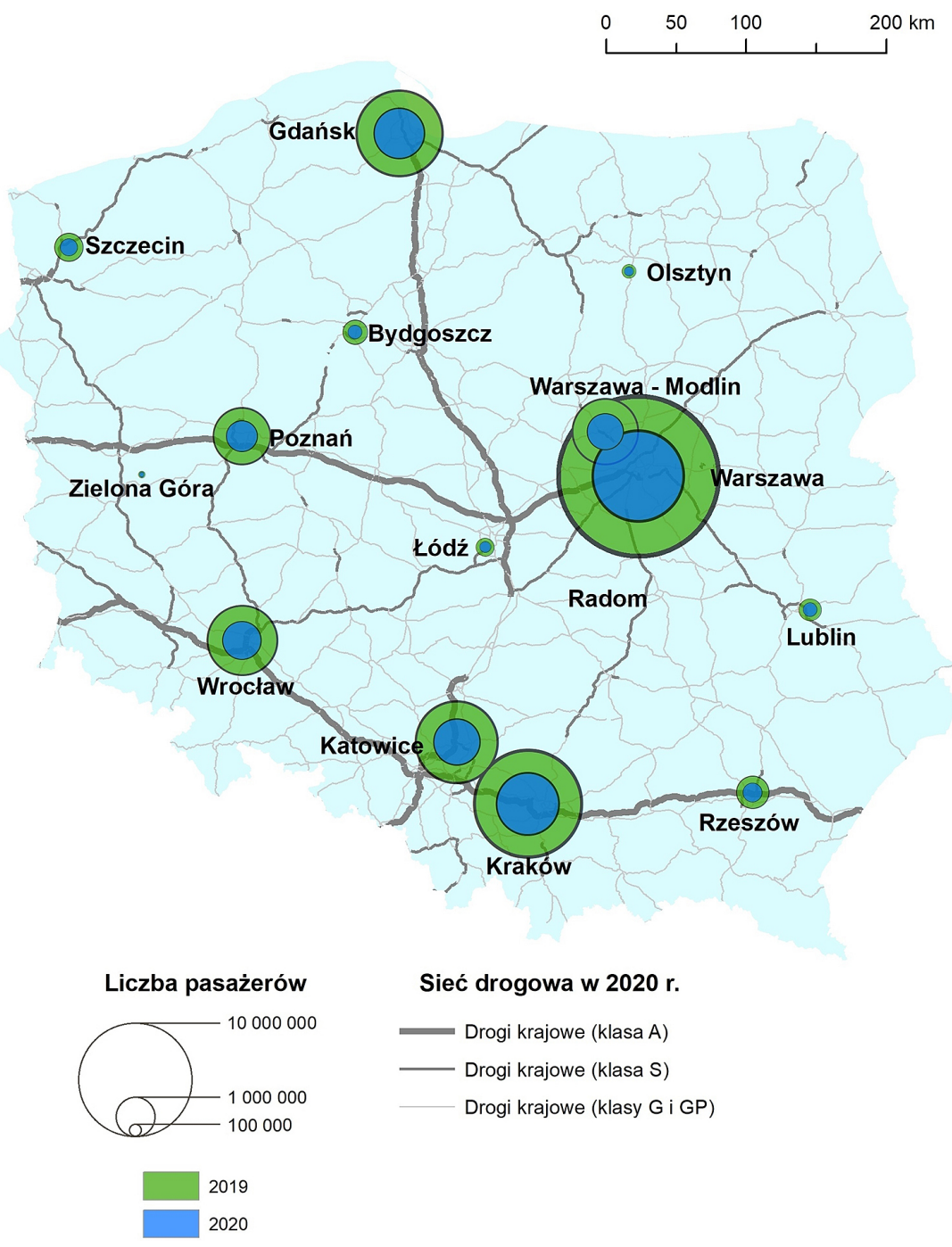

Ryc. 3. Liczba pasażerów obsłużonych w portach lotniczych w Polsce w latach 2019 i 2020

Źródło: opracowanie własne na podstawie danych ULC i bazy danych OSM (2021). 
Tabela 1. Liczba pasażerów obsłużonych w portach lotniczych w Polsce w latach 2019 i 2020

\begin{tabular}{lrrrc}
\hline \multirow{2}{*}{$\begin{array}{l}\text { Miasto - port } \\
\text { lotniczy }\end{array}$} & \multicolumn{2}{c}{ Liczba pasażerów } & $\begin{array}{c}\text { Różnica w liczbie } \\
\text { pasażerów w latach }\end{array}$ & $\begin{array}{c}\text { Udział liczby pasażerów } \\
\text { z roku 2020 w liczbie } \\
\text { pasażerów z roku 2019 }\end{array}$ \\
\cline { 2 - 5 } Warszawa & \multicolumn{1}{c}{2019} & \multicolumn{1}{c}{2020} & 2020 i 2019 & $29,04 \%$ \\
Kraków & 8402859 & 2588970 & -5813889 & $30,81 \%$ \\
Gdańsk & 5361134 & 1697406 & -3663728 & $31,66 \%$ \\
Katowice & 4843650 & 1437876 & -3405774 & $29,69 \%$ \\
Wrocław & 3543398 & 1003066 & -2540332 & $28,31 \%$ \\
Modlin & 3104277 & 870831 & -2233446 & $28,05 \%$ \\
Poznań & 2372184 & 652833 & -1719351 & $27,52 \%$ \\
Rzeszów & 769252 & 234355 & -534897 & $30,47 \%$ \\
Szczecin & 580479 & 185848 & -394631 & $32,02 \%$ \\
Bydgoszcz & 413472 & 124545 & -288927 & $30,12 \%$ \\
Lublin & 356011 & 123512 & -232499 & $34,69 \%$ \\
Eódź & 241707 & 75275 & -166432 & $31,14 \%$ \\
Olsztyn & 147446 & 61114 & -86332 & $41,45 \%$ \\
Zielona Góra & 33078 & 19266 & -13812 & $58,24 \%$ \\
Radom & 0 & 0 & $0,00 \%$ \\
\hline Polska & 49013538 & 14548121 & -34465417 & $30,81 \%$ \\
\hline
\end{tabular}

Źródło: opracowanie własne na podstawie danych ULC (2021).

z kolei po wybuchu pandemii w roku 2020 liczba ta wyniosła jedynie 652 tys., co oznacza 27,5\% pasażerów w stosunku do roku 2019. Powyższe dane wskazują na znaczący spadek liczby osób korzystających z usług lotniska. Co istotne, spośród wszystkich funkcjonujących w kraju (poza Radomiem) portów poznańskie lotnisko straciło największy odsetek liczby pasażerów z roku 2019, warto jednakże zaznaczyć, że różnice w tej kwestii pomiędzy portami podobnej klasy są niewielkie (przykładowo port we Wrocławiu obsłużył 28,3\% liczby pasażerów z roku 2019). Powyższy wynik skutkuje docelowo zmniejszeniem zasięgu oddziaływania lotniska w stosunku do roku 2019.

Interesujące wyniki przynosi analiza liczby pasażerów obsłużonych w porcie w podziale na segmenty ruchu lotniczego. Okazuje się, że pandemia COVID-19 znacząco wpłynęła na zmiany w strukturze połączeń realizowanych z Poznania. Poza spadkiem liczby pasażerów $w$ odniesieniu do każdego $z$ analizowanych segmentów w porównaniu do danych z roku 2019 wzrósł udział segmentu połączeń regularnych i niskokosztowych, natomiast znaczący spadek odnotowano w przypadku sektora czarterów. Jest to związane przede wszystkim ze zmianami, które zaszły na rynku. $Z$ uwagi na brak zleceń firmy realizujące połączenia czarterowe częściowo zawiesiły działalność, a w ich miejsce touroperatorzy korzystali z usług 
Tabela 2. Podział ruchu w Porcie Lotniczym Poznań-Ławica w 2019 i 2020 r.

\begin{tabular}{lcrrrrr}
\hline Rok & \multicolumn{2}{c}{ Ruch regularny } & \multicolumn{2}{c}{ Ruch niskokosztowy } & \multicolumn{2}{c}{ Ruch czarterowy } \\
\hline 2019 & 488868 & $20,54 \%$ & 1152098 & $48,41 \%$ & 734791 & $30,88 \%$ \\
2020 & 141547 & $21,52 \%$ & 379744 & $57,74 \%$ & 134343 & $20,43 \%$ \\
\hline
\end{tabular}

Źródło: opracowanie własne na podstawie danych Portu Lotniczego Poznań-Ławica (2021).

przewoźników realizujących połączenia regularne lub niskokosztowe, którzy oferowali loty w kierunkach atrakcyjnych turystycznie. Przykładowo w roku 2019 Polskie Linie Lotnicze LOT uruchomiły z Poznania 10 kierunków w ramach połączeń regularnych, które de facto realizowały częściowo funkcję połączeń czarterowych; korzystali z nich także touroperatorzy. W wyniku tego typu działań w roku 2020 udział ruchu czarterów zmniejszył się, przede wszystkim na skutek wpływu pandemii na działalność firm z sektora turystycznego.

Drugim elementem, który wpłynął na zasięg oddziaływania danego portu lotniczego, jest dostępność transportowa. $Z$ uwagi na fakt, że samochód jest najpopularniejszym środkiem transportu w celu dostania się na lotnisko, dla wyrażenia poziomu dostępności skorzystano z miary dostępności mierzonej odległością czasową, którą wyznaczono w oparciu o parametry techniczne sieci drogowej.

Ryciny 4 i 5 prezentują dostępność czasową portu lotniczego w Poznaniu w latach 2019 i 2020. Zasadniczo poziom dostępności w analizowanych latach nie zmienił się, $\mathrm{z}$ uwagi na niewielkie przekształcenia sieci drogowej $\mathrm{w}$ rzeczonym okresie. Zgodnie z informacjami podawanymi przez Generalną Dyrekcję Dróg Krajowych i Autostrad w 2020 r. oddano do użytku następujące odcinki dróg krajowych:

- DK28 obwodnica Sanoka $(6,7 \mathrm{~km})$,

- S61 obwodnica Szczuczyna - II jezdnia $(6,6 \mathrm{~km})$,

- S3/A6 Szczecin-Dąbie-Rzęśnica (3,5 km),

- DK20 obwodnica Węgorzyna (1 km),

- S17 Lubelska - początek obwodnicy Kołbieli (15,2 km),

- S17 obwodnica Kołbieli $(8,7 \mathrm{~km})$,

- S10 obwodnica Kobylanki, Morzyczyna i Zieleniowa - II jezdnia $(6,4 \mathrm{~km})$,

- A2 Lubelska - Halinów (5,6 km),

- A2 Halinów - obwodnica Mińska Mazowieckiego (9,2km),

- DK73 obwodnica Dąbrowy Tarnowskiej (6,9 km),

- S5 Szubin Północ-Żnin Północ (19,3 km),

- S10 obwodnica Wałcza $(17,8 \mathrm{~km})$,

- S5 Bydgoszcz-Opławiec-Bydgoszcz-Błonie (13,5 km),

- S2 POW Warszawa-Wilanów-Wał Miedzeszyński (6,4km),

- S2 POW Wał Miedzeszyński-Lubelska (7,4km),

- S17 węzeł Lubelska (3,5 km). 


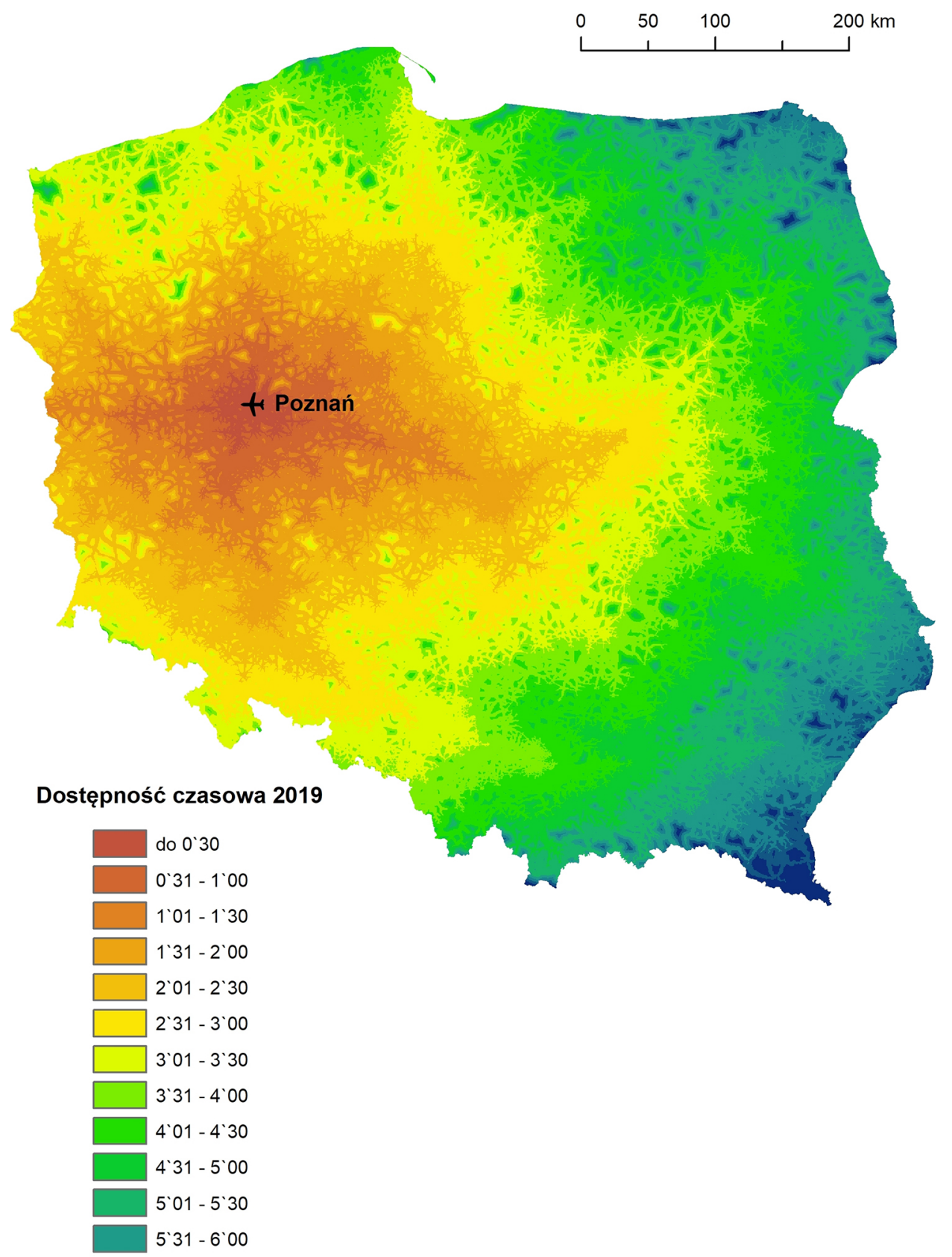

Ryc. 4. Dostępność czasowa Portu Lotniczego Poznań-Ławica w 2019 r.

Źródło: opracowanie własne. 


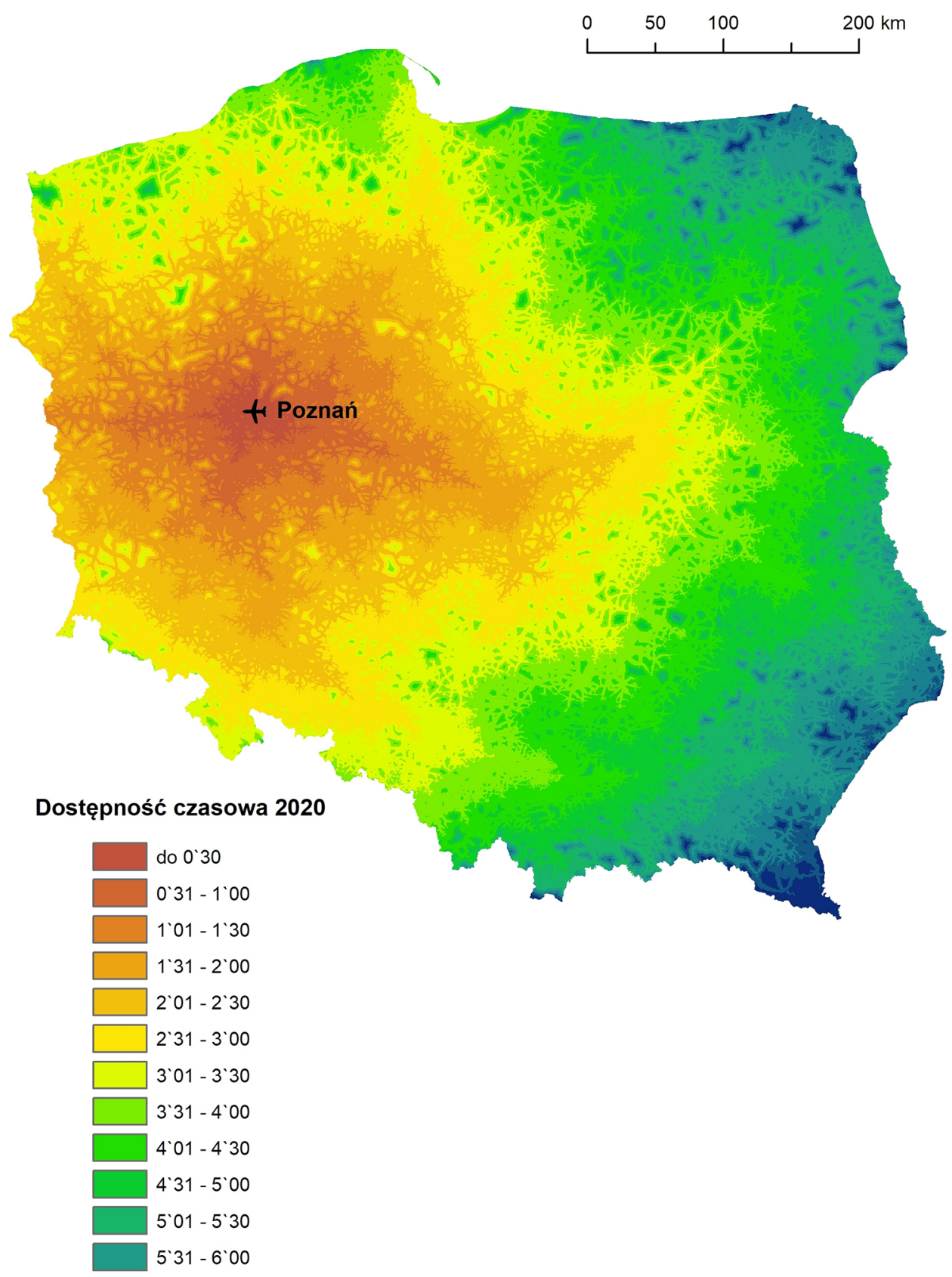

Ryc. 5. Dostępność czasowa Portu Lotniczego Poznań-Ławica w $2020 \mathrm{r}$.

Źródło: opracowanie własne. 
Rozbudowa sieci o te odcinki dróg przełożyła się w bardzo nieznacznym stopniu na zmianę dostępności Portu Lotniczego Poznań-Ławica. Z uwagi na lokalizację lotniska w centralno-zachodniej części kraju jest ono relatywnie dobrze dostępnym obiektem. Szczególnie dobra dostępność czasowa cechuje miejscowości zlokalizowane przy głównej sieci drogowej, w tym przede wszystkim przy drogach A2, S5 i S11. Zmiana dostępności transportowej (przedstawiona na ryc. 6) wska-

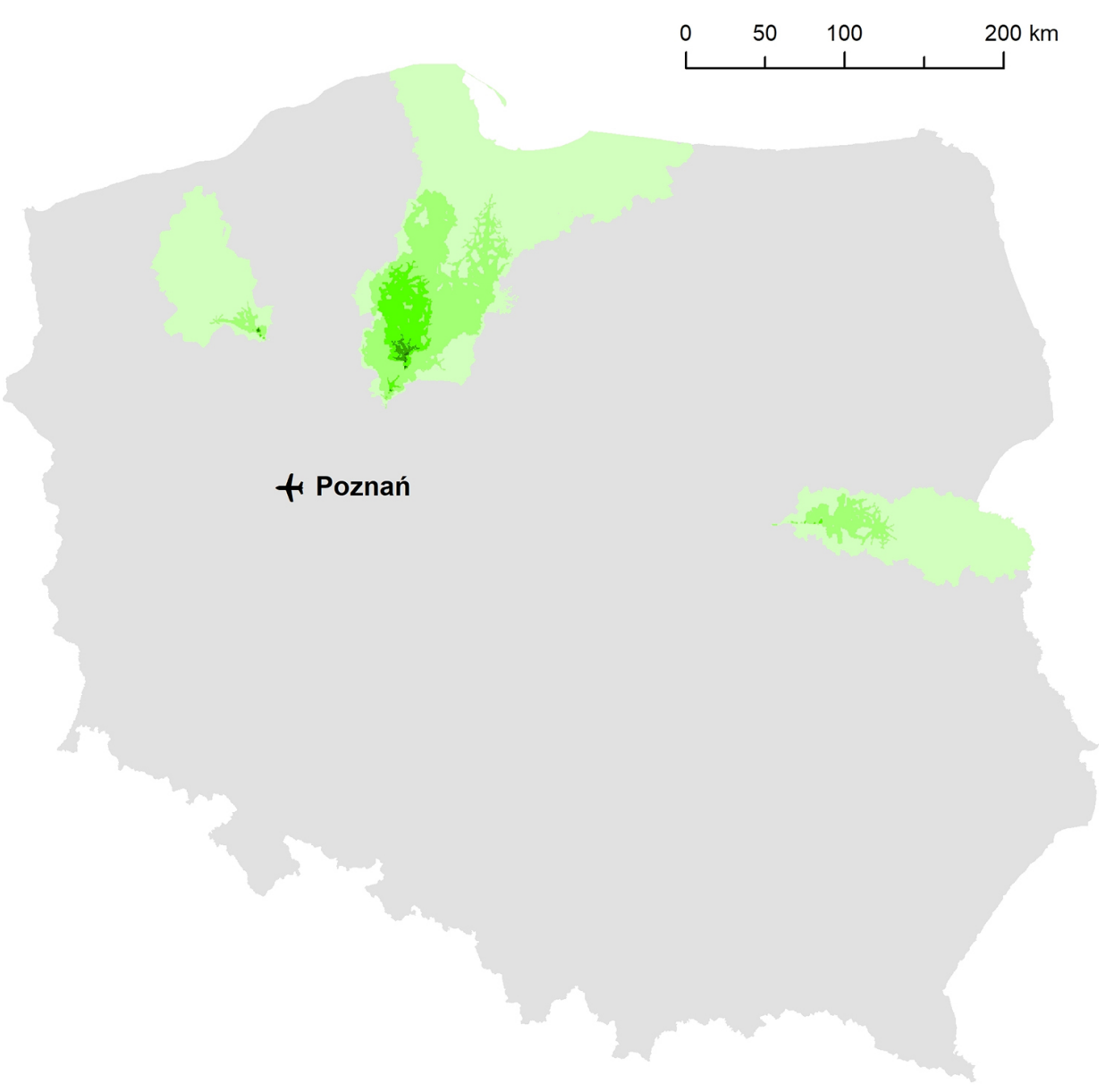

Zmiana dostępności czasowej w 2020 r.

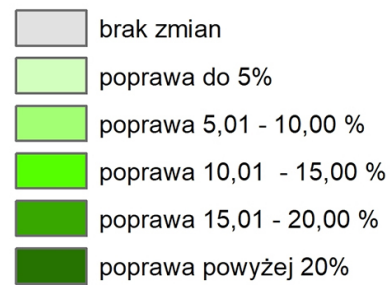

Ryc. 6. Zmiana $\mathrm{w}$ dostępności czasowej Portu Lotniczego Poznań-Ławica w $2020 \mathrm{r}$.

Źródło: opracowanie własne. 
zuje na poprawę czasu dojazdu do portu lotniczego w Poznaniu przede wszystkim z obszarów, które zyskały nową infrastrukturę drogową, głównie o parametrach autostrady i drogi ekspresowej. Największa poprawa dostępności w przypadku dojazdu do lotniska w Poznaniu nastąpiła z kierunku północno-wschodniego (Bydgoszcz, Gdańsk), na co wpływ miało oddanie do użytku nowych odcinków drogi ekspresowej S5, wschodniej części kraju (Siedlec, Białej Podlaskiej), co było skutkiem budowy odcinków autostrady A2 i drogi ekspresowej S2 na wschód od Warszawy, oraz okolic Wałcza i Pomorza Środkowego (na co wpływ miała rozbudowa obwodnicy Wałcza w ciągu drogi S10). Pozostałe inwestycje drogowe nie wpłynęły w znaczącym stopniu na zmianę dostępności portu lotniczego, na co wskazuje analiza ryciny 6. Warto zaznaczyć, że pandemia COVID-19 (w ujęciu modelowym) też nie wpłynęła na zmiany dostępności transportowej.

\section{Zasięg oddziaływania portu}

Podstawowym celem opracowania było określenie zasięgu oddziaływania portu lotniczego w Poznaniu oraz zmian tego oddziaływania na skutek pandemii COVID-19. W tym celu w oparciu o przedstawioną metodologię wykonano opracowania kartograficzne, prezentujące analizowane zjawisko. Aby ustalić zasięg oddziaływania poznańskiego portu lotniczego i pozostałych portów, przeprowadzono analizy porównawcze w oparciu o dane dotyczące dostępności i potencjału Portu Lotniczego Poznań-Ławica i pozostałych 14 portów lotniczych w kraju.

Wyniki analiz przedstawionych na rycinie 7 wskazują na regionalny zasięg portu lotniczego, przy czym warto zaznaczyć, że siła oddziaływania lotniska maleje wraz z odległością. Biorąc pod uwagę oddziaływanie innych portów lotniczych w kraju można wskazać, że prawdopodobieństwo skorzystania z usług portu największe jest w centralnej części województwa wielkopolskiego. Obszar, z którego prawdopodobieństwo wyboru lotniska wynosi ponad 50\%, wyznacza ekwidystanta około $40-50 \mathrm{~km}$ od lotniska. Na pozostałym obszarze kraju prawdopodobieństwo wyboru Poznania jako miejsca skorzystania z usług w ramach transportu lotniczego jest już znacznie mniejsze i wynosi często poniżej $10 \%$. Zasięg izolinii prezentującej poziom prawdopodobieństwa wyboru do $30 \%$ wskazuje na silne oddziaływanie lotniska na obszar centralnej części województwa wielkopolskiego i znacznej części województwa lubuskiego. Należy jednak pamiętać, że analizy nie uwzględniają oddziaływania portu lotniczego w Berlinie, co z pewnością ma istotny wpływ na wyniki badania. Dostrzega się także oddziaływanie na niewielkie fragmenty województw: zachodniopomorskiego, lubuskiego i dolnośląskiego.

Wyniki analiz dla roku 2020 (ryc. 8) wskazują na drobne zmiany zasięgu oddziaływania portu, dostrzega się niewielkie ograniczenie strefy wyższego prawdopodobieństwa skorzystania z usług. Wpływ na ten wynik ma przede wszystkim 
zmniejszenie liczby połączeń realizowanych z Poznania, co przełożyło się na liczbę obsłużonych pasażerów w 2020 r. Jak już wspomniano w przypadku Poznania, odsetek osób, które port utracił, jest wyższy aniżeli w przypadku innych portów, co oznacza, że relatywnie znaczenie portu w skali kraju zmniejszyło się. Wyniki przedstawione na rycinie 8 wskazują, że oddziaływanie portu obniżyło

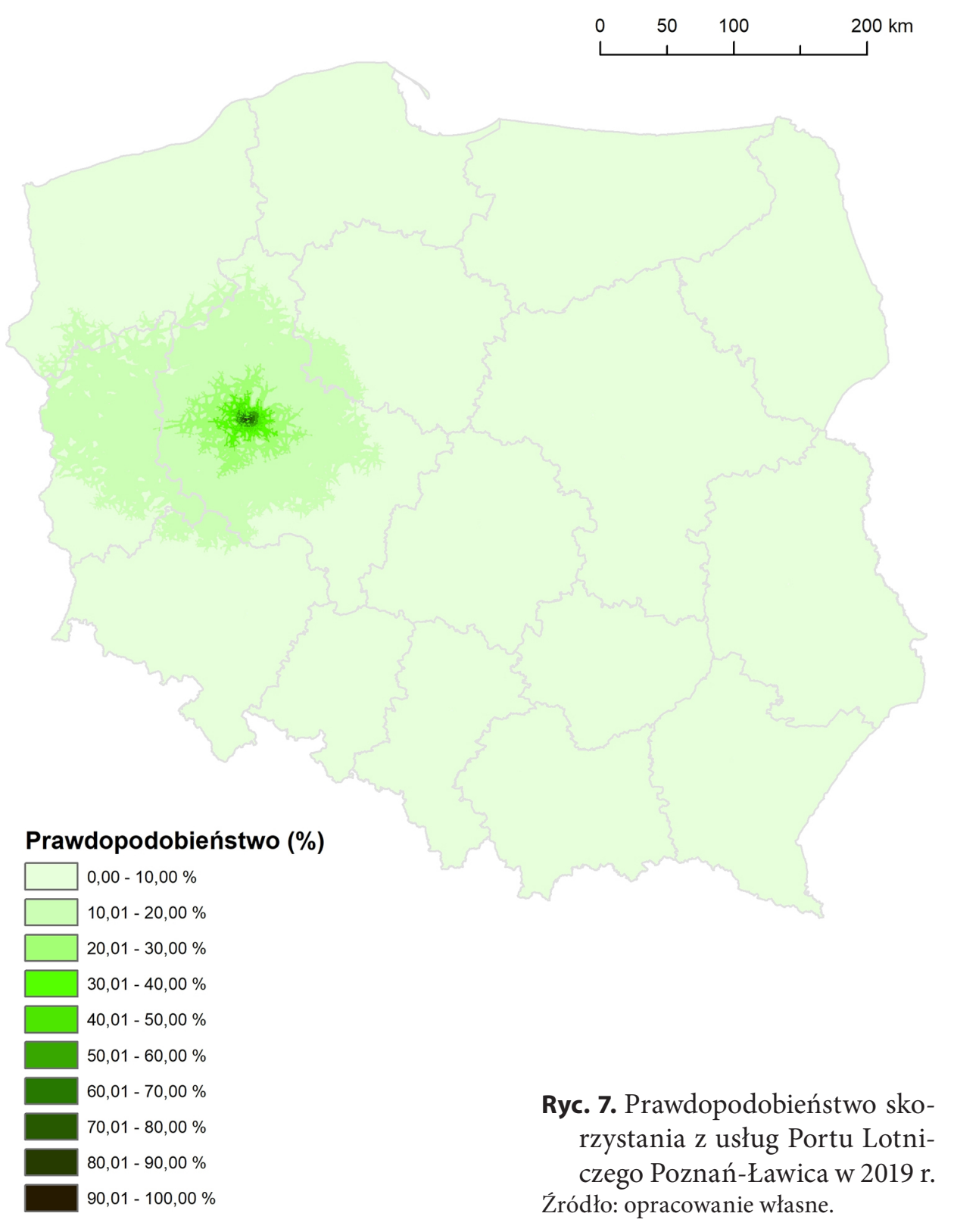


się, zwłaszcza wyraźnie zmalało prawdopodobieństwo skorzystania z jego usług przez mieszkańców województwa lubuskiego.

Rycina 9 przedstawia zmiany zasięgu oddziaływania Portu Lotniczego Poznań-Ławica w latach 2019-2020. Wyniki badań wskazują jednoznacznie na obniżenie znaczenia portu w ciągu analizowanego okresu. Ograniczenie zasię-

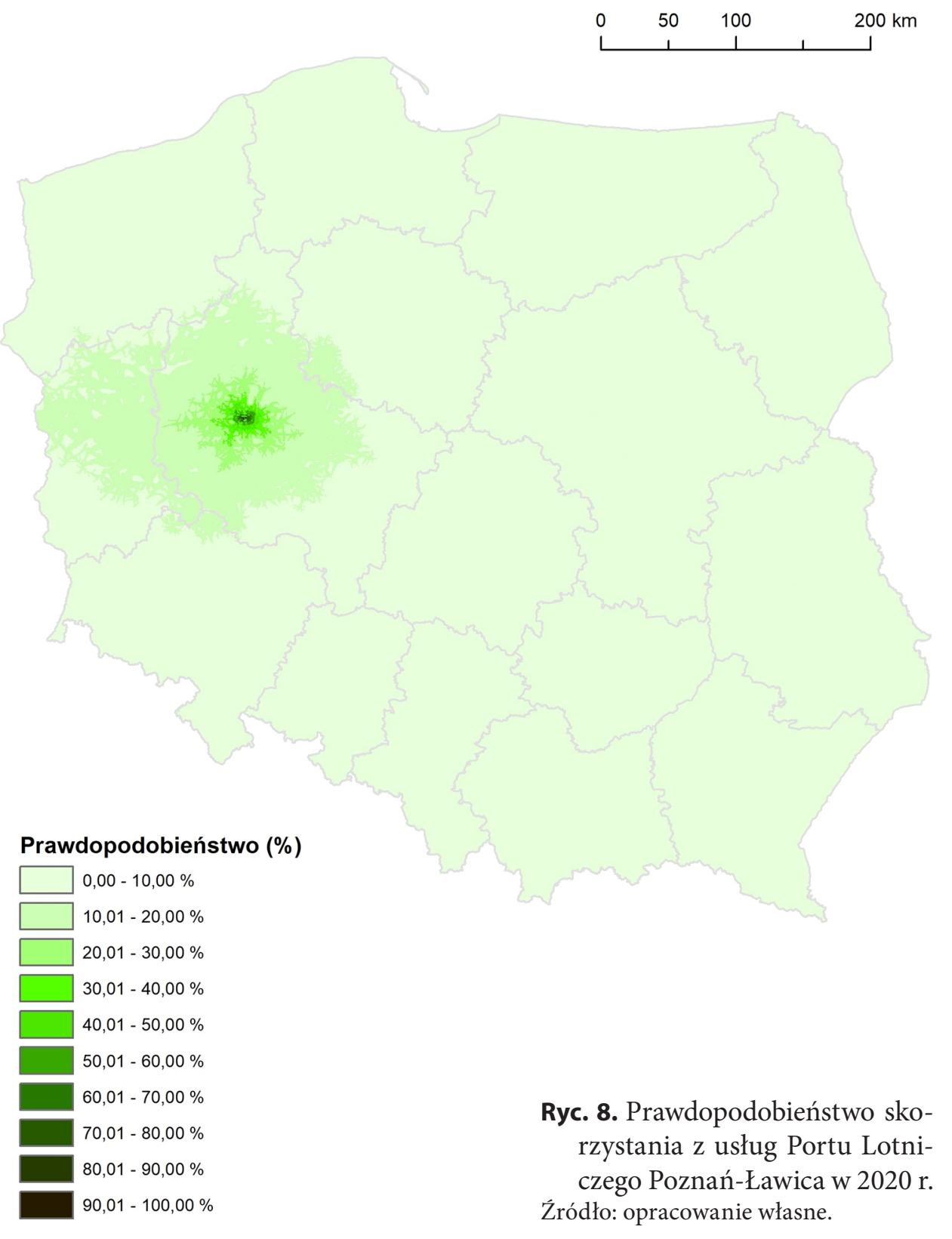


gu oddziaływania portu wynika wprost z utraty liczby pasażerów przez lotnisko, a także braku wyraźnej poprawy dostępności transportowej. Jedynym obszarem, $\mathrm{w}$ przypadku którego wzrosło prawdopodobieństwo skorzystania $\mathrm{z}$ lotniska, jest zachodnia część województwa kujawsko-pomorskiego, co jest rezultatem poprawy dostępności transportowej. Pozostałe obszary w kraju cechują się obniżeniem poziomu prawdopodobieństwa skorzystania z usług lotniska w Poznaniu, w tym

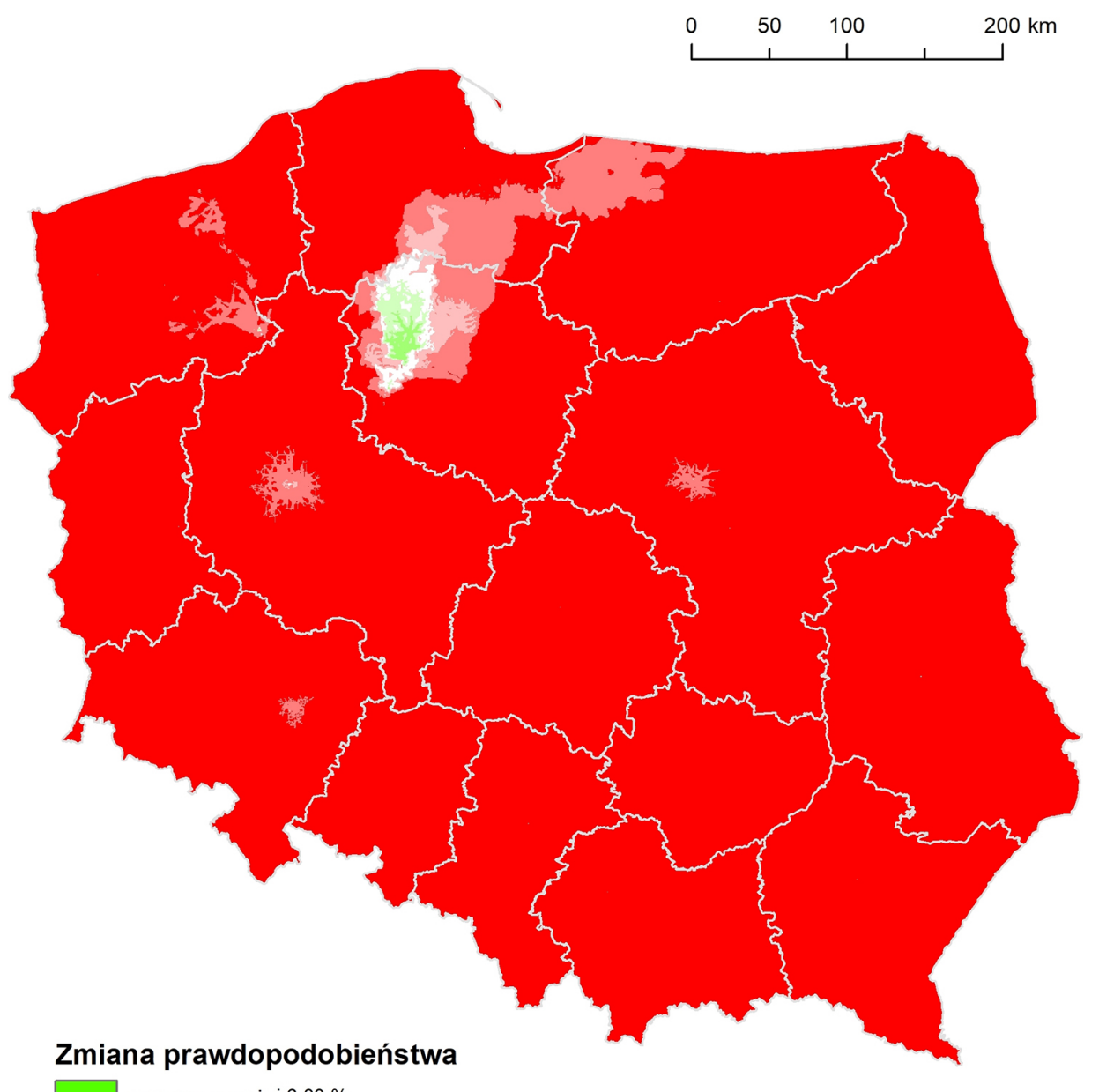

Ryc. 9. Zmiana prawdopodobieństwa skorzystania $z$ usług Portu Lotniczego Poznań-Ławica w $2020 \mathrm{r}$.

Źródło: opracowanie własne. 
w zdecydowanej większości kraju prawdopodobieństwo jest mniejsze o ponad 6\% (maksymalnie 11\%).

Interesujące wyniki badań przedstawiono na rycinie 10, która prezentuje sumaryczne zestawienie prawdopodobieństwa skorzystania z usług wszystkich analizowanych portów lotniczych w Polsce. Wyniki analiz wskazują na dominującą rolę warszawskiego Lotniska Chopina w systemie połączeń lotniczych w kraju. Jednocześnie strefy dominacji miast mających port lotniczy o znaczeniu regio-

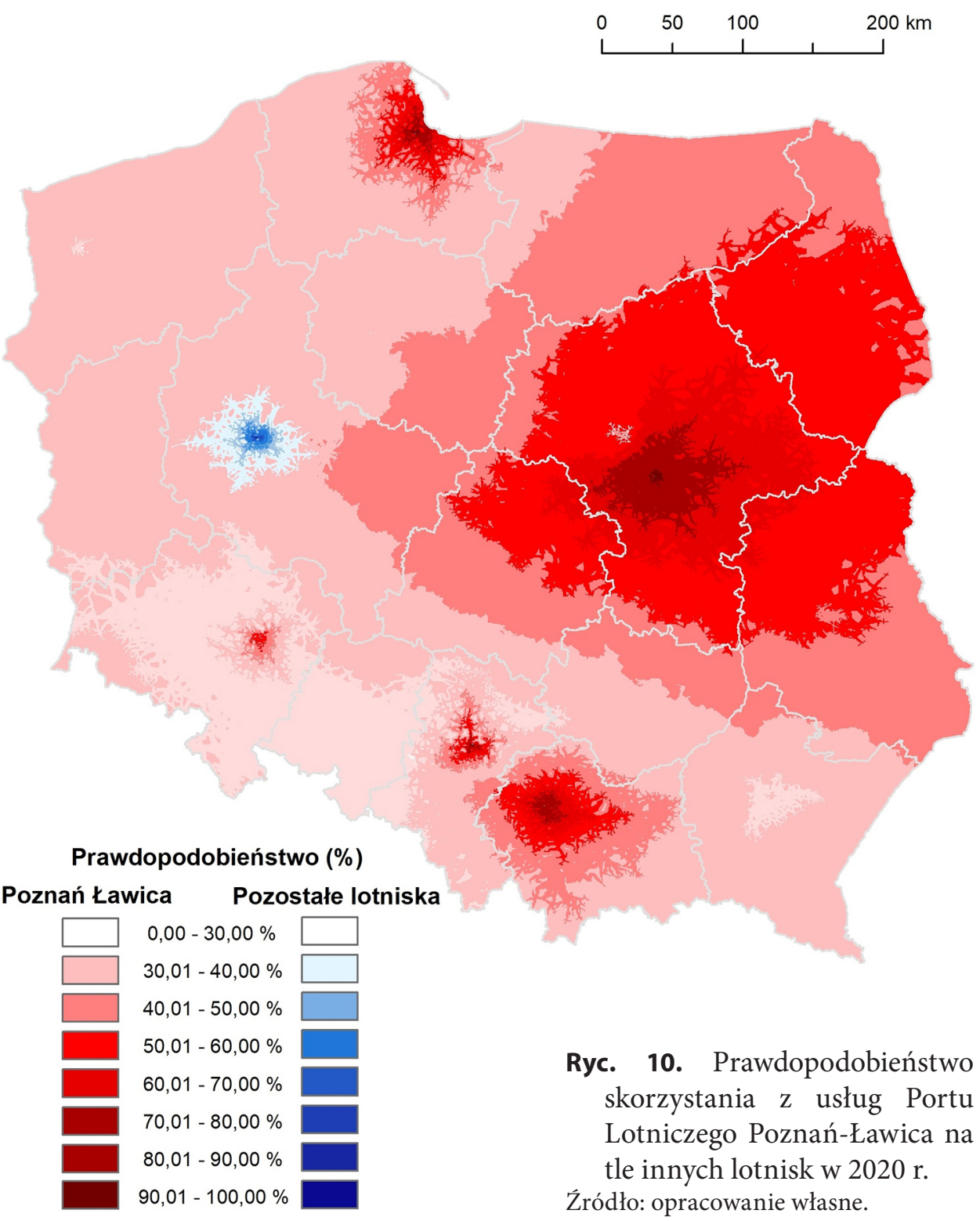


nalnym są bardzo zróżnicowane wielkościowo (Bul, 2018). Lotniska w Krakowie, Gdańsku, Poznaniu, Wrocławiu czy Katowicach są obiektami o zasięgu intensywnego oddziaływania ograniczonego promieniem $40-60 \mathrm{~km}$ od miast, z kolei pozostałe porty lotnicze $\mathrm{w}$ kraju praktycznie takiej strefy nie mają. Jest to pochodna dużo gorszej oferty w przypadku lotnisk regionalnych aniżeli Warszawy oraz niższego poziomu dostępności czasowej, przy czym tutaj różnica nie jest drastyczna, a część ośrodków (Łódź, Poznań, Wrocław) cechuje podobna dostępność jak w przypadku stolicy.

Rycina 10 wskazuje też na pewien problem z zastosowaniem modelu Huffa do oceny zasięgu oddziaływania portów o zróżnicowanym potencjale. Dominacja w modelu portu lotniczego w Warszawie jest tak wyraźna (z uwagi na wysoki potencjał), że część wyników wydaje się nie do końca zgodna z rzeczywistością (np. granica oddziaływania pomiędzy Poznaniem i Warszawą znajduje się na wysokości Kostrzyna, około $30 \mathrm{~km}$ od Poznania). Z uwagi na specyfikę tej metody wydaje się, że model mógłby znaleźć zastosowanie w przypadku porównania portów tej samej klasy, np. Poznań-Wrocław (patrz Bul, 2018) czy Kraków-Katowice. Drugi problem wynikający z wykorzystania modelu Huffa to kwestia określenia znaczenia granic państwowych, co jest szczególnie istotne w czasie pandemii. Z powodu zmieniającej się sytuacji pandemicznej i związanych z nią problemów przy przekraczaniu granic rośnie znaczenie krajowych portów lotniczych. Zdaniem autora opracowania stosowanie modelu Huffa w obecnych czasach bez uwzględnienia funkcjonowania granic państwowych byłoby znaczącym błędem mającym wpływ na wynik końcowy, stąd decyzja o przeprowadzeniu analizy w skali kraju.

\section{WNIOSKI}

Polskie porty lotnicze od kilkunastu miesięcy funkcjonują w zupełnie nowej, mocno nieprzewidywalnej rzeczywistości. Jak wskazuje Kubas (2020), prawdziwa wydaje się teza Williego Walsha, prezesa AIG, który określił kryzys wywołany pandemią Covid-19 jako największy kryzys w historii współczesnego lotnictwa. Warto podkreślić, że pandemia COVID-19 zahamowała intensywny rozwój, którego przez ostatnie lata doświadczały porty lotnicze, co wpłynęło m.in. na sytuację ekonomiczną lotnisk. Port Lotniczy Poznań-Ławica jest w tej kwestii bardzo szczególnym przypadkiem, gdyż z uwagi na wyznaczenie obszaru ograniczonego użytkowania wokół lotniska, podmiot zarządzający portem zmuszony był już do wypłacenia odszkodowań (do 2020 r.) w kwocie $118 \mathrm{mln}$ zł (Roczne sprawozdanie finansowe..., 2020). To wraz ograniczeniem dochodów w okresie funkcjonowania lotniska w trakcie trwania pandemii przekłada się na bardzo złą sytuację ekonomiczną portu. Szacuje się, że dochód z działalności lotniska w roku 2020 spadł do $35 \mathrm{mln}$ zł (w roku 2019 było to $90 \mathrm{mln}$ zł). Pandemia nie ułatwia zatem działalności portu, który w ostatnim czasie przeżywa duże problemy finansowe. 
Port Lotniczy Poznań-Ławica jest niewątpliwie typowym przykładem portu regionalnego, jego podstawową funkcją jest zapewnienie dobrej dostępności transportowej mieszkańcom województwa wielkopolskiego. Warto podkreślić, że lokalizacja w danym mieście znaczącego portu lotniczego generuje wiele korzyści dla danego ośrodka i jest identyfikatorem funkcji metropolitalnych. Każde miasto aspirujące do rangi metropolii powinno zatem starać się wzmacniać pozycję konkurencyjną własnego portu lotniczego w kontekście sąsiednich lotnisk (Bul, 2018). Należy zatem działać na rzecz zapewnienia dobrej oferty przewozowej $\mathrm{w}$ ramach transportu lotniczego, nawet $\mathrm{w}$ trakcie trwania pandemii.

Celem artykułu było określenie zasięgu oddziaływania Portu Lotniczego Poznań-Ławica w kontekście funkcjonowania pozostałych lotnisk w kraju. Wyniki analiz wskazują, że pozostałe lotniska w znaczącym stopniu oddziałują na region i na rynek usług lotniczych na obszarze województwa wielkopolskiego. Lotnisko Ławica jest obiektem pierwszego wyboru przede wszystkim dla mieszkańców centralnej części Wielkopolski, z kolei im bliżej granicy województwa, tym większe można dostrzec oddziaływanie konkurencyjnych portów lotniczych. Duże znaczenie ma w tym względzie oferta połączeń dostępna z poszczególnych lotnisk i częstotliwość lotów. Wyniki badań wskazują także na niewielkie zmniejszenie się zasięgu oddziaływania lotniska w związku ze skutkami, jakie wywołała pandemia. Największy wpływ na ten rezultat ma ograniczenie liczby pasażerów obsłużonych na lotnisku, w wartościach względnych większe aniżeli w innych portach w kraju.

Nie da się ukryć, że pandemia COVID-19 mocno zmieniła sposób funkcjonowania transportu lotniczego w kraju. Wydaje się, że mocno wzrosło znaczenie transportu lotniczego w celu realizacji funkcji turystycznej. Doskonale widoczne jest to na przykładzie takich lotnisk jak Poznań, gdzie wyraźna intensyfikacja ruchu ma obecnie miejsce w okresach wakacyjno-urlopowych, natomiast ruch w pozostałych miesiącach jest mocno ograniczony. Jest to oczywiście związane z mniejszą liczbą zachorowań w okresie letnim, jednakże analiza liczby destynacji i oferowanych kierunków wskazuje na rosnące znaczenie połączeń o charakterze turystyczno-wypoczynkowym. Trudno przewidywać, jak ta sytuacja zmieni się w najbliższym czasie, dużą nadzieję na powrót do normalności daje program powszechnych szczepień, przy czym należy pamiętać o potencjalnych mutacjach wirusa, co wiąże się z możliwością wyodrębnienia się nowego wariantu odpornego na szczepionki. Jak wskazują informacje podawane przez IATA (Międzynarodowe Zrzeszenie Przewoźników Powietrznych), nowe warianty COVID-19 mogą znacząco przyczynić się do opóźnienia otwarcia niektórych rynków lotniczych (Walków, 2021). Co istotne, najnowsze prognozy podkreślają, że wskaźnik RPK (liczba pasażerów pomnożona przez odległości przez nich przebyte w ciągu roku) osiągnie poziom z 2019 r. dopiero w 2024 r. (Ekonomiczne skutki...), co oznacza, że odbudowa rynku zabierze dużo więcej czasu, aniżeli początkowo przewidywano. 
Ważnym celem realizowanym w pracy było również wykorzystanie modelu Huffa do określenia siły oddziaływania poszczególnych lotnisk. Jak wskazuje Młodzianowski (2017), model ten znajduje powszechne zastosowanie w praktyce gospodarczej. Na podstawie przeprowadzonych analiz wydaje się, że analizowany model może być wykorzystywany do określania potencjału rynku usług lotniczych w kontekście dostępności danego portu lotniczego, pomimo faktu, że został on pierwotnie stworzony dla analiz z zakresu handlu i usług komercyjnych (Plichta, 1998). Główną zaletą modelu jest możliwość przeprowadzenia symulacji udziału skorzystania $\mathrm{z}$ usług poszczególnych portów w różnych częściach kraju. Zastosowanie powyższego modelu umożliwia także pozyskanie interesujących danych przestrzennych bez konieczności prowadzenia długotrwałych i kosztownych badań terenowych (Migdał-Najman, Mudza, 2009). Oczywiście należy pamiętać o ograniczeniach tej metody, która nie uwzględnia istotnych czynników oddziałujących na wybór danego lotniska, takich jak chociażby ceny połączeń czy wpływu granic państwowych na wybór oferty portu przez osoby zainteresowane usługami lotniczymi. Z tego też względu trudno na podstawie powyższego modelu wysnuwać głębsze wnioski w kontekście dostępności i potencjału przyciągania polskich pasażerów chociażby przez lotnisko w Berlinie (Bul, 2018). Problematyczne może być także zastosowanie tego modelu w przypadku miast obsługiwanych przez kilka portów lotniczych, zlokalizowanych w różnych miejscach, ale mających bezpośredni wpływ na wielkość oferty przewozowej realizowanej z danego miasta.

W kontekście powyższych badań należy podkreślić, że władze miejskie i regionalne powinny troszczyć się o rozwój poznańskiego portu lotniczego. Warto pamiętać, że transport lotniczy odgrywa bardzo istotną rolę w gospodarce każdego kraju i regionu (Tłoczyński, 2017). Sytuacja pandemiczna niewątpliwie wymusiła wiele zmian na rynku usług lotniczych w Polsce, co może być symptomem zmiany sposobu działalności branży i rozszerzenia oferty, a tym samym wzrostu znaczenia lotniska. Z punktu widzenia oferty połączeń należałoby dążyć do rozwoju sieci przede wszystkim w segmencie połączeń regularnych i niskokosztowych. Poznańskie lotnisko cechuje się też dużym potencjałem w zakresie ruchu czarterowego (co zostało dostrzeżone przez touroperatorów), ważne jest zatem rozszerzenie siatki połączeń także w skali ponadkontynentalnej. Duże znaczenie w kontekście zasięgu oddziaływania danego lotniska ma jego dostępność transportowa (głównie drogowa), należałoby zatem prowadzić działania na rzecz jak najszybszego ukończenia dróg ekspresowych S5 i S11, które to wraz z autostradą A2 stanowią kręgosłup sieci drogowej województwa wielkopolskiego i dzięki którym dostępność portu lotniczego będzie zdecydowanie lepsza. Rozwój oferty i poprawa dostępności powinny służyć rozwojowi portu zarówno w czasie trwania pandemii, jak i po jej zakończeniu. 


\section{LITERATURA}

Abate M., Christidis P., Purwanto A.J. (2020). Government support to airlines in the aftermath of the COVID-19 pandemic. Journal of Air Transport Management, 89: 1-15.

Augustyniak W., Olipra Ł. (2014). The potential catchment area of Polish regional airports. Journal of International Studies 7(3): 144-154. https://doi.org/10.14254/20718330.2014/7-3/13

Brol W. (2014). Analiza konkurencji lotnisk - model Huffa. WB Data (https://wbdata.pl/ model-huffa-dla-lotnisk; dostęp: 15.06.2021).

Bul R. (2018). Oferta i siła oddziaływania lotniska Poznań-Ławica na obszar województwa wielkopolskiego w kontekście funkcjonowania sąsiednich portów lotniczych. Rozwój Regionalny i Polityka Regionalna, 44: 67-89.

Chojnicki Z. (2011). Zakres i warunki zastosowania modelu potencjału w badaniach przestrzenno-ekonomicznych. W: Z. Chojnicki, T. Czyż, W. Ratajczak (red.), Model potencjału. Podstawy teoretyczne $i$ zastosowania $w$ badaniach przestrzenno-ekonomicznych oraz regionalnych. Bogucki Wyd. Nauk., Poznań.

Czyż T. (2002). Application of the potential model to the analysis of regional differences in Poland. Geographia Polonica, 75: 13-24.

Ekonomiczne skutki pandemii COVID-19 dla lotnictwa. Strona internetowa Portu Lotniczego Kraków (https://krakowairport.pl/blog/ekonomiczne-skutki-pandemii-covid-19-dla-lotnictwa-cywilnego/; dostęp: 24.08.2021).

Gadziński J. (2013). Funkcjonowanie lokalnego system transportowego na tle współczesnych procesów urbanizacyjnych. Przykład aglomeracji poznańskiej. Bogucki Wyd. Nauk., Poznań.

Huff D.L. (1963). A Probabilistic Analysis of Shopping Centre Trade Areas, Land Economics, 38(1): 81-90.

Huff D.L. (1964). Defining and Estimating a Trading Area. Journal of Marketing, 28, 3: 34-38.

Juliao R.P. (1998). Measuring Accessibility: a GIS based methodology for accessibility evaluation. GIS PlaNET'98 Proceedings.

Ki-Han S., Solsaem C. (2020). A Study on the Behavioral Change of Passengers on Sustainable Air Transport after COVID-19. Sustainability, 12: 9207. https://doi.org/10.3390/ su12219207

Migdał-Najman K., Mudza A. (2009). Zastosowanie modelu grawitacji względnej Huffa w analizie rynku wielkopowierzchniowych placówek handlowych, Marketing $i$ Rynek, 3: 27-34.

Młodzianowski P. (2017). Identyfikacja praktycznych obszarów zastosowania modeli ekonofizycznych. Zeszyty Naukowe Politechniki Częstochowskiej, Zarządzanie, 28: 64-78.

Nizetić S. (2020). Impact of coronavirus (COVID-19) pandemic on air transport mobility, energy, and environment. A case study. International Journal of Energy Research, 44: 10953-10961. https://doi.org/10.1002/er.5706

Paprocki W. (2020). Sektor lotniczy wobec pandemii COVID-19. Ekspertyza 13. Open Eyes Economy Summit (https://www.google.com/url?sa=t\&rct=j\&q=\&esrc=s\&source=web\&cd=\&ved=2ahUKEwiwptXm7d_xAhXN-ioKHS5sD_YQFnoECAYQAA\&ur- 
l=https\%3A\%2F\%2Foees.pl\%2Fdownload\%2F1495622\%2F\&usg=AOvVaw3J1pSR4Cgb5oIq_RmujuYB; dostęp: 20.06.2021).

Pijet-Migoń E. (2012). Zmiany rynku lotniczych przewozów pasażerskich w Polsce po akcesji do Unii Europejskiej. Rozprawy Naukowe Instytutu Geografii i Rozwoju Regionalnego Uniwersytetu Wrocławskiego, 25.

Plichta G. (1998). Model Huffa jako narzędzie wspierające decyzje lokalizacyjne dużych obiektów handlowych. Zeszyty Naukowe, Akademia Ekonomiczna w Krakowie, 513: 109-120.

Roczne sprawozdanie finansowe Portu Lotniczego Poznań-Ławica za rok 2020. Port Lotniczy Poznań-Ławica (https://www.imsig.pl/krs/0000003431/sprawozdania/4308903, roczne_sprawozdanie_finansowe; dostęp: 4.09.2021).

Serrano F., Kazda A. (2020). The future of airports post COVID-19. Journal of Air Transport Management, 89. https://doi.org/10.1016/j.jairtraman.2020.101900

Taşdemir M. (2020). The Effects Of COVID-19 Pandemic To The Aviation Sector And Comparison of Turkish Major Airports Effiency Evaluation Before and During Pandemic Conditions with Data Envelopment Analysis Method. International Social Mentality and Researcher Thinkers Journal, 6(39): 2691-2707.

Tłoczyński D. (2016). Konkurencja na polskim rynku usług transportu lotniczego. Wydawnictwo Uniwersytetu Gdańskiego, Gdańsk.

Tłoczyński D. (2017). Potencjał konkurencyjności podmiotów sektora transportu lotniczego jako determinanta rozwoju dostępności czasowej i drogowej do portów lotniczych. Przegląd Komunikacyjny, 2: 31-36.

Walków M. (2021). Linie lotnicze nadal w kryzysie. Sa kolejne pomysty, jak przekonać pasażerów do powrotu do latania (https://businessinsider.com.pl/firmy/strategie/pay-when-you-fly-linie-lotnicze-w-kryzysie-w-2021-r-po-pandemii-covid-19/zg0xtnx; dostęp: 4.09.2021).

Zając G. (2020). Kryzys lotniczy w związku z Coronawirusem. Przegląd Komunikacyjny. 11: $13-18$. 